\title{
Oral Findings and Inherited Disorders of Platelet Function
}

\author{
Oral Bulgular ve Kalıtsal Trombosit İşlevi Bozuklukları
}

\author{
Beuy Joob $^{1}$, Viroj Wiwanitkit ${ }^{2}$ \\ ${ }^{1}$ Sanitation 1, Medical Academic Center, Bangkhae, Bangkok, Thailand \\ ${ }^{2}$ Wiwanitkit House, Bangkhae, Bangkok, Thailand
}

\section{To the Editor,}

The recent report on oral findings and inherited disorders of platelet function (IDPF) was very interesting [1]. Hatipoglu et al. concluded that, "IDPF have a negative effect on periodontal tissues [1]." I would like to raise some relevant issues. First, there are many factors that can cause periodontal disorders, such as behavior, nutrition, and other underlying diseases [2], which were not completely investigated in their study. Hence, the conclusion of a direct relationship might not be warranted. Second, the measured platelet parameters and their relationship to periodontal disease would be an interesting focus of further study. A recent publication showed that there wasn't a clinical correlation between the platelet count and periodontal disorder, but between mean platelet volume and periodontal disorder in the study group [3].

\section{References}

1. Hatipoglu MG, Kansu O, BüyükaşıkY. Clinical investigation of oral findings in inherited disorders of platelet function. Turk J Hematol. 2011; 28(4): 294-298.

2. Kornman KS.Mapping the pathogenesis of periodontitis: a new look. J P eriodontol. 2008 Aug;79(8 Suppl):1560-8.

3. López R, Loos BG, Baelum V. Hematological features in adolescents with periodontitis. Clin Oral Investig. 2011 Oct 19. [Epub ahead of print]

\section{Reply,}

I would like to thank authors of the letter for their suggestions. This study used a case-controlled design and, as we noted in the report, the aim of the study was to identify clinical oral findings in IDPF patients. Care was taken for similar hematological aspects. Patients with other systemic diseases or conditions were excluded from the study and control groups, and we attempted to differentiate behavioral, nutritional, and underlying disease etiologies from those that were hematological.

Inherited platelet function disorders were the primary focus of the study, which showed that was indicated molecular and biochemical studies in this topic which has been started in recent times [1-3]. We think that more comprehensive studies are needed to further delineate the effect of IDPF on periodontium.

\section{Assist. Prof. Müjgan Güngör Hatipoğlu,}

Department of Oral, Tooth and Jaw Radiology, University of Dumlupinar, Faculty of Dentistry, Kütahya, Turkey

\section{References}

1. Spolidorio LC, Herrera BS, Coimbra LS, Figueiredo MN, Spolidorio DM, Muscará MN. Short-term induction of thrombocytopenia delays periodontal healing in rats with periodontal disease: Participation of endostatin and vascular endothelial growth factor. J Periodontal Res 2010; 45 (2): 184-192 
2. Javed F, Al-Askar M, Al-Rasheed A, Al-Hezaimi K. Significance of the platelet-derived growth factor in periodontal tissue regeneration. Arch Oral Biol 2011; 56 (12): 1476-1484
3. Coimbra LS, Rossa C Jr, Guimarães MR, Gerlach RF, Muscará MN, Spolidorio DM, Herrera BS, Spolidorio LC. Influence of antiplatelet drugs in the pathogenesis of experimental periodontitis and periodontal repair in rats. J Periodontol $2011 ; 82$ (5): 767-777 